\title{
Relation of skinfold thickness and visceral fat with the endothelial function in Mexican postmenopausal women
}

\author{
Sebastián Carranza Lira, Ana Mirna Fino Muro, Sergio Rosales Ortiz \\ UMAE Hospital de Gineco Obstetricia “Luis Castelazo Ayala”, Instituto Mexicano del Seguro Social, Mexico City, Mexico
}

\begin{abstract}
Objective: To determine the relationship between skinfolds and visceral fat with vascular reactivity according to body weight, fat distribution and time since menopause in Mexican postmenopausal women.

Material and methods: In postmenopausal women, tricipital, suprailiac and subscapular skinfolds as well as blood pressure were measured, and body mass index (BMI) and waist-hip ratio (WHR) were calculated. Brachial artery Doppler ultrasound at baseline and after the hyperemic stimulus was done and Doppler parameters were assessed. For statistical analysis, Pearson and Spearman correlation analysis, as well as Student $t$ were used.

Results: Sixty-six postmenopausal women were studied; age was $54.5 \pm 7.4$ years. Skinfold thickness was related with subcutaneous and visceral fat. In all groups, the arterial diameter increased after the hyperemic stimulus among $6.5 \%$ and $9 \%$ of women. The pulsatility index decreased in the whole group and in those with $\mathrm{BMI} \leq 27, \mathrm{WHR} \leq 0.85$ and time since menopause $\leq 10$ years. Negative correlations were observed between the percentage of change in arterial dilatation and the subscapular skinfold and subcutaneous fat in the whole group and in the subgroups with BMI $>27$ and WHR $>0.85$.

Conclusions: Skinfolds are indirectly related with visceral fat, and skinfold thickness permit to conclude about impact in endothelial environment.
\end{abstract}

Key words: skinfold, vascular reactivity, visceral fat, endothelium.

\section{Introduction}

Cardiovascular disease is an important cause of mortality in postmenopausal women [1]. In Mexico, there is a high frequency of metabolic syndrome in postmenopausal women [2, 3] which has a narrow relationship with cardiovascular disease [4]. The increase in visceral fat (VF) is an important component of metabolic syndrome [5], which is associated with lipid and insulin sensitivity disorders [6-8]. Visceral fat has been measured using different technologies such as computed tomography or ultrasound [9].

Skinfold thickness (ST) has been correlated with disorders in lipids levels and blood pressure [10]. Skinfold thickness and waist-hip ratio (WHR) allow to determine the central location of corporal fat, whose increase is related to the cardiovascular risk [11], and ST positively correlates with the appearance of hypertension [12, 13].

Due to the loss of nitric oxide (NO) endothelial activity $[14,15]$ endothelial dysfunction can precede the cardiovascular illness for several years [16]. Brachial artery Doppler ultrasound is a non-invasive method for endothelial function evaluation [17]. Flow mediated dilatation (FMD) in peripheral arteries is related with that of coronary arteries $[18,19]$ and the resistive index
(RI) can help to predict morbidity and mortality due to cardiovascular disease [20,21].

In adolescents, a negative correlation of ST and body mass index (BMI) with the arterial dilatation after hyperemic stimulus has been found [22]. A study in postmenopausal women found that VF was inversely related with flux mediated vasoactivity [23]. However, this sort of studies does not exist in Mexican postmenopausal woman. Also it is not known how ST and body fat distribution are related in this group of women.

That is why the objectives of the present study were to determine the relationship of several skinfolds and visceral fat with the vascular reactivity and to detect the relation between ST and WHR in Mexican postmenopausal women according to body weight, fat distribution and time since menopause.

\section{Material and methods}

Postmenopausal women that attended the external consultation of the gynecologic endocrinology service were studied. They were questioned about age (years), age at menopause (years), time since menopause (years) and use of medications. Weight (kg), height (m), 
waist and hip perimeter (cm), ST (tricipital, subscapular and suprailiac, in $\mathrm{mm}$ ) and blood pressure $(\mathrm{mmHg})$ were measured. The body mass index (weight/height ${ }^{2}$ ) and WHR (waist perimeter/hip perimeter) were calculated.

For tricipital, subscapular and suprailiac ST measurement, a Lange type caliper and a technique already described [24] were used.

Afterwards, all women had a Doppler ultrasound of the brachial artery done with a Voluson 730 Pro equipment (General Electric Healthcare, Austria GmbH) with a 7.5 $\mathrm{MHz}$ probe. The arterial diameter (AD) was measured and the pulsatility index (PI) and RI were calculated. For this, the transducer was placed perpendicularly in the distal third of the brachial artery and the internal diameter was measured, when the double line pattern was clearly seen. Pulsatility index was calculated as follows: maximal systolic speed minus minimal diastolic speed divided by the average speed during the complete cycle, and RI: maximal systolic speed minus final diastolic speed divided by maximal systolic speed. The hyperemic stimulus was induced placing the sphygmomanometer cuff on the right arm and inflating it $50 \mathrm{mmHg}$ beyond the maximal systolic pressure for five minutes. Later on, the cuff was deflated and withdrawn, 60 seconds later $A D, P I$ and $\mathrm{RI}$ were measured again [25-27].

Finally, subcutaneous and visceral (intrabdominal) fat were measured with an abdominal ultrasound with a 3.5-MHz transducer, which was placed in the half line, $1 \mathrm{~cm}$ below the navel and subcutaneous fat (SF) was considered as the distance between the skin and the external face of the right abdominal $(\mathrm{cm})$ muscle and VF as the distance between the internal face of the right abdominal muscle and the anterior aorta wall [28].

For sample size calculation, the MedCalc Version 12.7.4.0 statistical program was used considering an $\alpha$ error of 0.01 , a $\beta$ error of 0.10 and a correlation of 0.6 , being calculated for 44 patients.

For statistical analysis, descriptive statistics were used; Pearson correlation analysis was carried out for BMI, WHR, tricipital, suprailiac and subscapular skinfolds, with baseline and post hyperemic stimulus AD, PI, and RI, SF and VF. For the correlation analysis of the percentages of change in AD, PI and RI, the Spearman's Rho was used due to the sample distribution. For the comparison among the groups, among obese and not obese, between those with superior or inferior body fat distribution and among postmenopausal women with $\leq 10$ years since menopause and with more than 10 years, Student's $t$ test for independent samples was used. For the comparison in each group of baseline and after hyperemic stimulus values, Student's $t$ test for related samples was used.

The protocol was approved by the Local Committee of Research and Ethics in Research with number
R-2013-3606-23 and the patients signed the informed consent form.

\section{Results}

Sixty-six postmenopausal women that attended to the Gynecologic Endocrinology consultation and did not take medications that can modify blood pressure were recruited.

In the whole group, the age was $54.5 \pm 7.4$ years, age at menopause $47.4 \pm 3.9$ years and time since menopause $7.1 \pm 6.2$ years. Systolic blood pressure was $109.1 \pm 12.5 \mathrm{mmHg}$ and diastolic blood pressure 71.4 $\pm 8.2 \mathrm{mmHg}$. Weight was $70.5 \pm 66 \mathrm{~kg}$, height 1.55 $\pm 0.06 \mathrm{~m}$, BMI $29.5 \pm 5.1$, waist perimeter $91.8 \pm 11.1 \mathrm{~cm}$, hip perimeter $105.6 \pm 10.3 \mathrm{~cm}$, WHR $0.87 \pm 0.05$. Skinfold thickness measures were: tricipital $23.1 \pm 10.3 \mathrm{~mm}$, suprailiac $22.7 \pm 10.8 \mathrm{~mm}$ and subscapular $22.5 \pm 11.5 \mathrm{~mm}$. Subcutaneous fat measured $2.92 \pm 0.93 \mathrm{~cm}$, VF 5.23 $\pm 1.86 \mathrm{~cm}$ and the SF/VF ratio $0.61 \pm 0.21$.

In the brachial artery measurements, those values prior to the hyperemic stimulus were AD $0.39 \pm 0.12 \mathrm{~cm}$, $\mathrm{PI} 5.27 \pm 2.4$, RI $1.04 \pm 0.38$; and those after the hyperemic stimulus, $A D 0.46 \pm 0.11 \mathrm{~cm}, \mathrm{PI} 4.3 \pm 2.18$ and RI $0.95 \pm 0.124$, the percentage of change in $A D$ was 7.0 (-52-29), the percentage of change in PI was 86.5 (-647.0-651.0) and the percentage of change in RI was 0 (-245.0-41.0).

In the correlation analysis, diastolic blood pressure correlated with WHR $(0.306, p<0.013)$, VF $(0.275$, $p<0.026)$ and between the SF/VF ratio $(-0.26$, $p<0.035)$ and among AD prior to the hyperemic stimulus and $\mathrm{BMI}(0.241, p<0.05)$.

The age correlated with the percentage of change in PI $(\rho=0.312, p<0.011)$ and the percentage of change in RI with the SF/VF ratio $(\rho=0.261, p<0.034)$.

With regard to the skinfolds, the tricipital skinfold correlated with BMI, WHR, the subcutaneous fat and VF and $A D$ prior to the hyperemic stimulus. A similar correlation was observed for the suprailiac skinfold, except for WHR. The subscapular skinfold correlated with the same parameters as the tricipital skinfold, but also with $\mathrm{PI}$ after the hyperemic stimulus and with the percentage of change in RI. Subcutaneous fat correlated with $B M I$, with VF and AD prior to the hyperemic stimulus, with the percentage of change in $\mathrm{PI}$ and the percentage of change in $\mathrm{Rl}$ and negatively with the percentage of change in AD (Table I and II).

When dividing the group according to $\mathrm{BMI}$, the measurements of the skinfolds, subcutaneous fat and VF were significantly greater in those with $\mathrm{BMI}>27$. In the other analyzed parameters, there were no statistically significant differences (Table III).

In the correlation analysis in the subgroup with BMI $\leq 27$, it was positive among the tricipital skinfold and $\mathrm{BMI}$, and subcutaneous fat and VF. The suprailiac skin- 
Tab. I. General data in the population divided according to body mass index (BMI), waist hip ratio (WHR) and time since menopause

\begin{tabular}{|c|c|c|c|c|c|c|}
\hline Factor & $\begin{array}{c}\mathrm{BMI} \leq 27 \\
(n=27)\end{array}$ & $\begin{array}{c}\text { BMI > } 27 \\
(n=39)\end{array}$ & $\begin{array}{c}\mathrm{WHR} \leq 0.85 \\
(n=22)\end{array}$ & $\begin{array}{c}\text { WHR }>0.85 \\
\quad(n=44)\end{array}$ & $\begin{array}{c}\text { Time since } \\
\text { menopause } \\
\leq 10 \text { years } \\
\quad(n=50)\end{array}$ & $\begin{array}{c}\text { Time since } \\
\text { menopause } \\
>10 \text { years } \\
(n=16)\end{array}$ \\
\hline Age (years) & $53.1 \pm 8.3$ & $55.5 \pm 6.6$ & $55.0 \pm 7.2$ & $54.2 \pm 7.5$ & $51.4 \pm 4.8^{i}$ & $64.0 \pm 5.7^{i}$ \\
\hline Age at menopause (years) & $45.8 \pm 4.2^{\mathrm{a}}$ & $48.4 \pm 3.3^{\mathrm{a}}$ & $47.1 \pm 3.4$ & $47.5 \pm 4.1$ & $47.3 \pm 4.0$ & $47.7 \pm 3.5$ \\
\hline Time since menopause (years) & $7.3 \pm 7.0$ & $7.0 \pm 5.7$ & $7.9 \pm 6.8$ & $6.7 \pm 5.9$ & $4.2 \pm 2.8$ & $16.3 \pm 4.7$ \\
\hline Systolic blood pressure (mmHg) & $109.5 \pm 12.3$ & $108.8 \pm 12.8$ & $107.5 \pm 13.8$ & $109.9 \pm 11.9$ & $110.0 \pm 12.6$ & $106.2 \pm 12.0$ \\
\hline Diastolic blood pressure (mmHg) & $69.6 \pm 8.1$ & $72.6 \pm 8.3$ & $69.1 \pm 8.8$ & $72.5 \pm 7.8$ & $71.5 \pm 8.2$ & $70.9 \pm 8.6$ \\
\hline Weight (kg) & $60.7 \pm 4.1^{b}$ & $77.4 \pm 10.7^{b}$ & $65.0 \pm 7.8^{f}$ & $73.3 \pm 12.7^{f}$ & $70.7 \pm 12.4$ & $70.0 \pm 10.5$ \\
\hline Height (m) & $1.57 \pm 0.05^{c}$ & $1.54 \pm 0.06^{c}$ & $1.55 \pm 0.05$ & $1.55 \pm 0.06$ & $1.55 \pm 0.05$ & $1.55 \pm 0.06$ \\
\hline BMI & $24.7 \pm 1.53^{d}$ & $32.7 \pm 4.0^{d}$ & $27.1 \pm 4.3^{g}$ & $30.7 \pm 5.1^{\mathrm{g}}$ & $29.5 \pm 5.1$ & $29.3 \pm 5.2$ \\
\hline Waist (cm) & $83.3 \pm 5.8^{d}$ & $97.6 \pm 10.1^{d}$ & $84.3 \pm 6.7^{h}$ & $95.5 \pm 11.0^{h}$ & $92.5 \pm 11.4$ & $89.7 \pm 10.2$ \\
\hline Hip (cm) & $98.8 \pm 6.2^{d}$ & $110.2 \pm 10.0^{d}$ & $104.2 \pm 8.8$ & $106.3 \pm 11.0$ & $106.4 \pm 10.2$ & $103.1 \pm 10.4$ \\
\hline WHR & $0.84 \pm 0.05^{e}$ & $0.89 \pm 0.05^{\mathrm{e}}$ & $0.81 \pm 0.03^{h}$ & $0.9 \pm 0.04^{h}$ & $0.89 \pm 0.05$ & $0.87 \pm 0.07$ \\
\hline
\end{tabular}

Results represent average \pm standard deviation

$\mathrm{BMI}$ - body mass index, WHR - waist hip ratio

${ }^{\mathrm{a}}=p<0.006,{ }^{\mathrm{b}}=p<0.001,{ }^{\mathrm{c}}=p<0.03,{ }^{\mathrm{d}}=p<0.001,{ }^{\mathrm{e}}=p<0.001,{ }^{\mathrm{f}}=p<0.007, \mathrm{~g}=p<0.006,{ }^{\mathrm{h}}=p<0.001,{ }^{\mathrm{i}}=p<0.001$

Tab. II. Values of skinfolds, subcutaneous fat, visceral fat and Doppler parameters according to body mass index (BMI), waist hip ratio (WHR) and time since menopause

\begin{tabular}{|c|c|c|c|c|c|c|}
\hline Factor & $\begin{array}{c}\mathrm{BMI} \leq 27 \\
(n=27)\end{array}$ & $\begin{array}{c}\text { BMI > } 27 \\
(n=39)\end{array}$ & $\begin{array}{l}\mathrm{WHR} \leq 0.85 \\
\quad(n=22)\end{array}$ & $\begin{array}{l}\text { WHR }>0.85 \\
\quad(n=44)\end{array}$ & $\begin{array}{l}\text { Time since } \\
\text { menopause } \\
\leq 10 \text { years } \\
(n=50)\end{array}$ & $\begin{array}{c}\text { Time since } \\
\text { menopause } \\
>10 \text { years } \\
(n=16)\end{array}$ \\
\hline Tricipital (mm) & $17.2 \pm 6.8^{\mathrm{a}}$ & $27.1 \pm 10.4^{a}$ & $19.4 \pm 10.4^{b}$ & $24.9 \pm 9.9^{b}$ & $22.6 \pm 10.2$ & $24.7 \pm 10.8$ \\
\hline Suprailiac (mm) & $15.0 \pm 6.1^{\mathrm{a}}$ & $28.1 \pm 10.1^{\mathrm{a}}$ & $19.8 \pm 10.6$ & $24.2 \pm 10.7$ & $22.7 \pm 10.3$ & $22.7 \pm 12.5$ \\
\hline Subscapular (mm) & $15.6 \pm 5.8^{\mathrm{a}}$ & $27.2 \pm 12.1^{\mathrm{a}}$ & $17.1 \pm 10.0^{c}$ & $25.2 \pm 11.3^{c}$ & $22.0 \pm 10.2$ & $24.1 \pm 15.0$ \\
\hline Subcutaneous fat $(\mathrm{cm})$ & $2.44 \pm 0.84^{a}$ & $3.26 \pm 0.85^{a}$ & $2.6 \pm 0.7^{b}$ & $3.1 \pm 1.0^{b}$ & $2.84 \pm 0.89$ & $3.19 \pm 1.04$ \\
\hline Visceral fat (cm) & $3.96 \pm 1.0^{\mathrm{a}}$ & $6.1 \pm 1.8^{a}$ & $4.64 \pm 2.0$ & $5.5 \pm 1.7$ & $5.22 \pm 1.9$ & $5.2 \pm 1.8$ \\
\hline $\begin{array}{l}\text { Subcutaneous fat/ } \\
\text { Visceral fat ratio }\end{array}$ & $0.65 \pm 0.24$ & $0.58 \pm 0.18$ & $0.62 \pm 0.20$ & $0.6 \pm 0.21$ & $0.6 \pm 0.2$ & $0.63 \pm 0.2$ \\
\hline PI Pre & $5.9 \pm 2.0$ & $4.8 \pm 2.6$ & $5.9 \pm 2.2$ & $5.0 \pm 2.5$ & $5.4 \pm 2.3$ & $5.0 \pm 2.6$ \\
\hline RI Pre & $1.01 \pm 0.82$ & $1.1 \pm 0.49$ & $1.02 \pm 0.82$ & $1.05 \pm 0.46$ & $1.06 \pm 0.43$ & $0.96 \pm 0.07$ \\
\hline Arterial diameter Pre $(\mathrm{cm})$ & $0.36 \pm 0.09$ & $0.41 \pm 0.14$ & $0.36 \pm 0.09$ & $0.40 \pm 0.13$ & $0.38 \pm 0.11$ & $0.42 \pm 0.14$ \\
\hline PI Post & $4.2 \pm 2.0$ & $4.4 \pm 2.3$ & $4.3 \pm 2.2$ & $4.3 \pm 2.2$ & $4.3 \pm 2.4$ & $4.4 \pm 1.5$ \\
\hline RI Post & $0.96 \pm 0.14$ & $0.95 \pm 0.11$ & $0.96 \pm 0.12$ & $0.95 \pm 0.13$ & $0.94 \pm 0.13$ & $0.99 \pm 0.09$ \\
\hline Arterial diameter Post (cm) & $0.44 \pm 0.13$ & $0.48 \pm 0.1$ & $0.45 \pm 0.12$ & $0.47 \pm 0.11$ & $0.45 \pm 0.11$ & $0.5 \pm 0.12$ \\
\hline$\%$ Change in $\mathrm{PI}$ & $\begin{array}{c}-169 \\
(-543.0425 .0)\end{array}$ & $\begin{array}{c}-53 \\
(-647-651)\end{array}$ & $\begin{array}{c}-148.5 \\
(-647-651)\end{array}$ & $\begin{array}{c}-61 \\
(-634-494)\end{array}$ & $\begin{array}{c}-141.5 \\
(-647-651)\end{array}$ & $\begin{array}{c}-42.5 \\
(-634-286)\end{array}$ \\
\hline \% Change in RI & $0(63-23)$ & $0(-245-41)$ & $0(-63-22)$ & $0.0(-245-41)$ & $0.0(-245-41)$ & $0.0(-7-22)$ \\
\hline $\begin{array}{l}\% \text { Change in the arterial diam- } \\
\text { eter }\end{array}$ & $7(-6-26)$ & $7.0(-53-29)$ & $9(-5-27)$ & $6.5(-53-29)$ & $7.5(-53-29)$ & $7.0(-18-26)$ \\
\hline
\end{tabular}

Results represent average \pm standard deviation, the percentage of change and are expressed in median (minimum and maximum)

$\mathrm{PI}$ - Pulsatility index, RI - resistive index, Pre - pre hyperemic stimulus, Post - post hyperemic stimulus, \% - percentage

Comparison between columns ${ }^{\mathrm{a}}=p<0.001,{ }^{\mathrm{b}}=p<0.039,{ }^{\mathrm{c}}=0.006$ 
Tab. III. Significant correlations in the whole group

\begin{tabular}{lccccc}
\hline Factor & Tricipital & Suprailiac & Subscapular & $\begin{array}{c}\text { Subcuta- } \\
\text { neous fat }\end{array}$ & Visceral fat \\
\hline BMI & $0.707,0.001$ & $0.795,0.001$ & $0.733,0.001$ & $0.534,0.001$ & $0.735,0.001$ \\
\hline WHR & $0.323,0.001$ & $0.294,0.017$ & $0.313,0.010$ \\
\hline Subcutaneous fat & $0.518,0.001$ & 0.545 .0 .001 & $0.645,0.001$ & $0.461,0.001$ \\
\hline Visceral fat & $0.590,0.001$ & $0.679,0.001$ & $0.582,0.001$ & $0.461,0.001$ & \\
\hline Subcutaneous fat/Visceral fat ratio & & & $0.343,0.005$ & $-0.586,0.001$ \\
\hline Arterial diameter Pre & $0.311,0.011$ & $0.303,0.013$ & $0.374,0.002$ & $0.319,0.009$ & \\
\hline PI Post & & $0.256,0.038$ & & $-0.255,0.039$ \\
\hline$\%$ Change in the arterial diameter & & & $0.274,0.026$ \\
\hline$\%$ Change in PI & & & & & \\
\hline$\%$ Change in RI & & & & & \\
\hline
\end{tabular}

Results represent Pearson correlation coefficient and only \% of change represents Spearman's $\rho$, and $p$ value

$\mathrm{BMI}$ - body mass index, WHR - waist hip ratio, PI - Pulsatility index, RI - resistive index, Pre - pre hyperemic stimulus, Post - post hyperemic stimulus,

$\%$ - percentage

fold correlated with BMI and VF. The subscapular skinfold correlated with BMI and SF.

The percentage of change in $\mathrm{PI}$ correlated with the age $(\rho=0.669, p<0.001)$ and with the time since menopause $(\rho=0.463, p<0.015)$. The percentage of change in RI correlated with the SF/VF ratio $(\rho=0.361$, $p=0.064)$.

In the subgroup with $\mathrm{BMI}>27$, systolic blood pressure correlated with the age $(-0.347, p<0.03)$ as well as each of skinfolds with $\mathrm{BMI}, \mathrm{SF}$ and VF and $\mathrm{AD}$ prior to the hyperemic stimulus (Table IV). Subcutaneous fat correlated with $\mathrm{BMI}$ and $\mathrm{AD}$ prior to the hyperemic stimulus; also with the percentage of change in $\mathrm{PI}$, the percentage of change in RI and negatively with the percentage of change in the arterial dilatation and VF with BMI and SF. The subscapular skinfold correlated with the percentage of change in AD (Table IV).

When dividing the group according to WHR, it was found that the tricipital skinfold, the subscapular skinfold and SF were significantly greater in the group with

Tab. IV. Significant correlations in the group with body mass index (BMI) $\leq 27$ and $\mathrm{BMI}>27$

\begin{tabular}{|c|c|c|c|c|c|c|c|c|c|c|}
\hline \multirow[t]{2}{*}{ Factor } & \multicolumn{2}{|c|}{ Tricipital } & \multicolumn{2}{|c|}{ Suprailiac } & \multicolumn{2}{|c|}{ Subscapular } & \multicolumn{2}{|c|}{ Subcutaneous fat } & \multicolumn{2}{|c|}{ Visceral fat } \\
\hline & $\begin{array}{l}\text { BMI } \\
\leq 27\end{array}$ & $\begin{array}{l}\text { BMI } \\
>27\end{array}$ & $\begin{array}{l}\mathrm{BMI} \\
\leq 27\end{array}$ & $\begin{array}{l}\text { BMI } \\
>27\end{array}$ & $\begin{array}{l}\text { BMI } \\
\leq 27\end{array}$ & $\begin{array}{l}\text { BMI } \\
>27\end{array}$ & $\begin{array}{l}\text { BMI } \\
\leq 27\end{array}$ & $\begin{array}{l}\mathrm{BMI} \\
>27\end{array}$ & $\begin{array}{l}\mathrm{BMI} \\
\leq 27\end{array}$ & $\begin{array}{l}\text { BMI } \\
>27\end{array}$ \\
\hline BMI & $\begin{array}{c}0.459 \\
(0.016)\end{array}$ & $\begin{array}{c}0.648 \\
(0.001)\end{array}$ & $\begin{array}{c}0.526 \\
(0.005)\end{array}$ & $\begin{array}{c}0.681 \\
(0.001)\end{array}$ & $\begin{array}{c}0.440 \\
(0.022)\end{array}$ & $\begin{array}{c}0.657 \\
(0.001)\end{array}$ & & $\begin{array}{c}0.432 \\
(0.006)\end{array}$ & & $\begin{array}{c}0.615 \\
(0.001)\end{array}$ \\
\hline Subcutaneous fat & $\begin{array}{c}0.415 \\
(0.031)\end{array}$ & $\begin{array}{c}0.396 \\
(0.013)\end{array}$ & & $\begin{array}{c}0.434 \\
(0.006)\end{array}$ & $\begin{array}{c}0.410 \\
(0.034)\end{array}$ & $\begin{array}{c}0.633 \\
(0.001)\end{array}$ & & & & $\begin{array}{c}0.374 \\
(0.019)\end{array}$ \\
\hline Visceral fat & $\begin{array}{c}0.428 \\
(0.026)\end{array}$ & $\begin{array}{c}0.446 \\
(0.004)\end{array}$ & $\begin{array}{c}0.398 \\
(0.040)\end{array}$ & $\begin{array}{c}0.540 \\
(0.001)\end{array}$ & & $\begin{array}{c}0.512 \\
(0.001)\end{array}$ & & $\begin{array}{c}0.374 \\
(0.019)\end{array}$ & & \\
\hline $\begin{array}{l}\text { Subcutaneous fat/ } \\
\text { Visceral fat ratio }\end{array}$ & & & & & $\begin{array}{c}0.459 \\
(0.016)\end{array}$ & & $\begin{array}{c}0.722 \\
(0.001)\end{array}$ & & $\begin{array}{l}-0.526 \\
(0.005)\end{array}$ & $\begin{array}{c}-0.721 \\
(0.0019)\end{array}$ \\
\hline Arterial diameter Pre & & $\begin{array}{c}0.356 \\
(0.026)\end{array}$ & & $\begin{array}{c}0.393 \\
(0.013)\end{array}$ & & $\begin{array}{l}0.495 \\
(0.001)\end{array}$ & & $\begin{array}{c}0.494 \\
(0.001)\end{array}$ & & \\
\hline PI Post & & & & & & $\begin{array}{c}0.327 \\
(0.042)\end{array}$ & & & & \\
\hline $\begin{array}{l}\% \text { Change in the } \\
\text { arterial diameter }\end{array}$ & & & & & & $\begin{array}{l}-0.378 \\
(0.018)\end{array}$ & & $\begin{array}{l}-0.426 \\
(0.007)\end{array}$ & & \\
\hline \% Change in $\mathrm{PI}$ & & & & & & & & $\begin{array}{c}0.390 \\
(0.014)\end{array}$ & & \\
\hline \% Change in RI & & & & & & & & $\begin{array}{c}0.393 \\
(0.0139)\end{array}$ & & \\
\hline
\end{tabular}

Results represent Pearson correlation coefficient and only \% of change represents Spearman's $\rho . p$ value in parenthesis

$\mathrm{BMI}$ - body mass index, PI - Pulsatility index, RI - resistive index, Pre - pre hyperemic stimulus, Post - post hyperemic stimulus, \% - percentage 
WHR $>0.85$ (Table III). In the correlation analysis in the subgroup with $\mathrm{WHR} \leq 0.85$, there was a correlation between diastolic blood pressure and WHR $(-0.527$, $p<0.012)$ as well as between each of the skinfolds and BMI, the subcutaneous fat and VF. The percentage of change in PI correlated with the age $(\rho=0.498$, $p<0.018)$ and negatively with diastolic blood pressure $(\rho=-0.568, p<0.006)$. The percentage of change in AD correlated with the diastolic blood pressure $(\rho=0.426$, $p<0.048)$. The percentage of change in $\mathrm{RI}$ correlated with the tricipital skinfold $(\rho=0.450, p<0.036)$ and SF $(\rho=0.439, p<0.041)$ (Table V).

In the subgroup with WHR $>0.85$, the diastolic blood pressure correlated with WHR $(0.293, p=0.054)$, with VF $(0.299, p=0.049)$ and with the SF/VF ratio $(-0.357, p=0.017)$. Also, ST correlated with BMI, SF, VF and AD prior to the hyperemic stimulus. Subcutaneous fat correlated with BMI and WHR and the percentage of change in PI correlated with BMI $(\rho=0.316$, $p<0.037$ ), the suprailiac skinfold and the subcutaneous fat and VF. The percentage of change in RI correlated with SF. The percentage of change in AD correlated negatively with the diastolic blood pressure $(\rho=-0.293$, $p<0.053$ ), positively with the subscapular skinfold and negatively with the tricipital and suprailiac skinfolds and with SF (Table V).

When dividing the groups according to the time since menopause of $\leq 10$ years or $>10$ years, it was found in the former group that the diastolic blood pressure correlated with WHR $(0.289, p<0.042)$, VF $(0.322$, $p<0.022)$, the SF/VF ratio $(-0.355, p<0.011)$ and $\mathrm{BMI}$
(0.300, $p<0.034)$. Body mass index correlated with each of the skinfolds and the two types of fat. So did WHR with exception of the suprailiac skinfold. Subcutaneous fat and VF correlated with each of the three skinfolds.

The percentage of change in $\mathrm{PI}$ correlated with the suprailiac skinfold; the percentage of change in RI correlated with SF and this correlated negatively with the percentage of change in $\mathrm{AD}$ (Table $\mathrm{VI}$ ).

In the group with more than 10 years since menopause, BMI correlated with each of the three skinfolds and with two types of fat. Also, each of the skinfolds correlated with two types of fat, and the subscapular skinfold correlated with AD prior to the hyperemic stimulus (Table VI). Body mass index correlated with the percentage change in $\mathrm{RI}(\rho=0.507, p<0.045)$ and with the tricipital and subscapular skinfolds and SF (Table VI). The percentage of change in $A D$ correlated negatively with the age $(\rho=-0.648, p<0.007)$.

When comparing pre and post hyperemic stimulus measurements, in the whole group, a significant decrease in $\mathrm{PI}(5.3 \pm 2.4$ vs. $4.3 \pm 2.2, p<0.012)$ and a significant increase in $A D(0.39 \pm 0.12 \mathrm{~cm}$ vs. $0.46 \pm 0.11 \mathrm{~cm}$, $p<0.001$ ) were found.

When dividing according to $\mathrm{BMI}$, in those with $\mathrm{BMI}$ $\leq 27$ there was a significant decrease in $\mathrm{PI}(5.9 \pm 2.0$ vs. $4.2 \pm 2.0, p<0.002)$ and a significant increase in $A D$ $(0.36 \pm 0.09 \mathrm{~cm}$ vs. $0.44 \pm 0.13 \mathrm{~cm}, p<0.001)$. In those with $\mathrm{BMI}>27$, only a significant increase in AD (0.41 \pm $0.14 \mathrm{~cm}$ vs. $0.48 \pm 0.1 \mathrm{~cm}, p<0.006)$ was found.

When dividing according to WHR, in those with $W H R \leq 0.85$, there was a significant decrease in $\mathrm{PI}(5.9 \pm$

Tab. V. Significant correlations in the group with the waist hip ratio (WHR) $\leq 0.85$ and $>0.85$

\begin{tabular}{|c|c|c|c|c|c|c|c|c|c|c|}
\hline \multirow[t]{2}{*}{ Factor } & \multicolumn{2}{|c|}{ Tricipital } & \multicolumn{2}{|c|}{ Suprailiac } & \multicolumn{2}{|c|}{ Subscapular } & \multicolumn{2}{|c|}{ Subcutaneous fat } & \multicolumn{2}{|c|}{ Visceral fat } \\
\hline & $\begin{array}{l}\text { WHR } \\
\leq 0.85\end{array}$ & $\begin{array}{c}\text { WHR } \\
>0.85\end{array}$ & $\begin{array}{l}\text { WHR } \\
\leq 0.85\end{array}$ & $\begin{array}{c}\text { WHR } \\
>0.85\end{array}$ & $\begin{array}{l}\text { WHR } \\
\leq 0.85\end{array}$ & $\begin{array}{l}\text { WHR } \\
>0.85\end{array}$ & $\begin{array}{l}\text { WHR } \\
\leq 0.85\end{array}$ & $\begin{array}{c}\text { WHR } \\
>0.85\end{array}$ & $\begin{array}{l}\text { WHR } \\
\leq 0.85\end{array}$ & $\begin{array}{l}\text { WHR } \\
>0.85\end{array}$ \\
\hline $\mathrm{BMI}$ & $\begin{array}{c}0.675 \\
(0.001) \\
\end{array}$ & $\begin{array}{c}0.692 \\
(0.001) \\
\end{array}$ & $\begin{array}{c}0.877 \\
(0.001) \\
\end{array}$ & $\begin{array}{c}0.758 \\
(0.001) \\
\end{array}$ & $\begin{array}{c}0.695 \\
(0.001) \\
\end{array}$ & $\begin{array}{c}0.701 \\
(0.001) \\
\end{array}$ & $\begin{array}{c}0.597 \\
(0.003) \\
\end{array}$ & $\begin{array}{c}0.468 \\
(0.001) \\
\end{array}$ & $\begin{array}{c}0.732 \\
(0.001)\end{array}$ & $\begin{array}{r}0.726 \\
(0.001) \\
\end{array}$ \\
\hline WHR & & & & & & & & & & $\begin{array}{c}0.359 \\
(0.017)\end{array}$ \\
\hline Subcutaneous fat & $\begin{array}{c}0.726 \\
(0.001)\end{array}$ & $\begin{array}{c}0.416 \\
(0.005)\end{array}$ & $\begin{array}{c}0.663 \\
(0.001)\end{array}$ & $\begin{array}{c}0.489 \\
(0.001)\end{array}$ & $\begin{array}{c}0.688 \\
(0.001)\end{array}$ & $\begin{array}{c}0.599 \\
(0.001)\end{array}$ & & $\begin{array}{c}0.402 \\
(0.007)\end{array}$ & $\begin{array}{c}0.552 \\
(0.008)\end{array}$ & $\begin{array}{c}0.402 \\
(0.007)\end{array}$ \\
\hline Visceral fat & $\begin{array}{c}0.614 \\
(0.001)\end{array}$ & $\begin{array}{c}0.537 \\
(0.001)\end{array}$ & $\begin{array}{c}0.705 \\
(0.001)\end{array}$ & $\begin{array}{c}0.646 \\
(0.001)\end{array}$ & $\begin{array}{l}0.545 \\
(0.009)\end{array}$ & $\begin{array}{c}0.564 \\
(0.001)\end{array}$ & $\begin{array}{c}0.552 \\
(0.008)\end{array}$ & $\begin{array}{c}0.472 \\
(0.001)\end{array}$ & & \\
\hline $\begin{array}{l}\text { Subcutaneous fat/ } \\
\text { Visceral fat ratio }\end{array}$ & & & & & & & & & $\begin{array}{l}-0.676 \\
(0.001)\end{array}$ & $\begin{array}{l}-0.545 \\
(0.001)\end{array}$ \\
\hline Arterial diameter Pre & & $\begin{array}{c}0.448 \\
(0.002)\end{array}$ & & $\begin{array}{c}0.503 \\
(0.001)\end{array}$ & & $\begin{array}{c}0.570 \\
(0.001)\end{array}$ & & $\begin{array}{l}0.459 \\
(0.002)\end{array}$ & & \\
\hline $\begin{array}{l}\% \text { Change in } \\
\text { the arterial diameter }\end{array}$ & & $\begin{array}{l}-0.316 \\
(0.037)\end{array}$ & & $\begin{array}{l}-0.395 \\
(0.008)\end{array}$ & & $\begin{array}{c}0.382 \\
(0.011)\end{array}$ & & $\begin{array}{l}-0.332 \\
(0.028)\end{array}$ & & \\
\hline$\%$ Change in $\mathrm{Pl}$ & & & & $\begin{array}{c}0.391 \\
(0.009)\end{array}$ & & & & $\begin{array}{c}0.394 \\
(0.008)\end{array}$ & & $\begin{array}{l}0.297 \\
(0.05)\end{array}$ \\
\hline \% Change in RI & $\begin{array}{c}0.450 \\
(0.036)\end{array}$ & & & & & & $\begin{array}{c}0.439 \\
(0.041)\end{array}$ & $\begin{array}{c}0.308 \\
(0.042)\end{array}$ & & \\
\hline
\end{tabular}

Results represent Pearson correlation coefficient and only \% of change represents Spearman's $\rho . p$ value in parenthesis

$\mathrm{BMI}$ - body mass index, WHR - waist hip ratio, PI - pulsatility index, RI - resistive index, Pre - pre hyperemic stimulus, $\%$ - percentage 
Tab. VI. Significant correlations in the group with time since menopause $\leq 10$ years and $>10$ years

\begin{tabular}{|c|c|c|c|c|c|c|c|c|c|c|}
\hline \multirow[t]{2}{*}{ Factor } & \multicolumn{2}{|c|}{ Tricipital } & \multicolumn{2}{|c|}{ Suprailiac } & \multicolumn{2}{|c|}{ Subscapular } & \multicolumn{2}{|c|}{ Subcutaneous fat } & \multicolumn{2}{|c|}{ Visceral fat } \\
\hline & $\begin{array}{l}\leq 10 \\
\text { years }\end{array}$ & $\begin{array}{l}>10 \\
\text { years }\end{array}$ & $\begin{array}{l}\leq 10 \\
\text { years }\end{array}$ & $\begin{array}{l}>10 \\
\text { years }\end{array}$ & $\begin{array}{l}\leq 10 \\
\text { years }\end{array}$ & $\begin{array}{l}>10 \\
\text { years }\end{array}$ & $\begin{array}{l}\leq 10 \\
\text { years }\end{array}$ & $\begin{array}{l}>10 \\
\text { years }\end{array}$ & $\begin{array}{l}\leq 10 \\
\text { years }\end{array}$ & $\begin{array}{l}>10 \\
\text { years }\end{array}$ \\
\hline $\mathrm{BMI}$ & $\begin{array}{c}0.694 \\
(0.001)\end{array}$ & $\begin{array}{c}0.769 \\
(0.001)\end{array}$ & $\begin{array}{c}0.783 \\
(0.001)\end{array}$ & $\begin{array}{c}0.835 \\
(0.001)\end{array}$ & $\begin{array}{c}0.717 \\
(0.001)\end{array}$ & $\begin{array}{c}0.815 \\
(0.001)\end{array}$ & $\begin{array}{c}0.464 \\
(0.001)\end{array}$ & $\begin{array}{c}0.771 \\
(0.001)\end{array}$ & $\begin{array}{c}0.734 \\
(0.001)\end{array}$ & $\begin{array}{c}0.738 \\
(0.001)\end{array}$ \\
\hline WHR & $\begin{array}{c}0.317 \\
(0.025)\end{array}$ & & & & $\begin{array}{c}0.420 \\
(0.002)\end{array}$ & & $\begin{array}{c}0.301 \\
(0.033)\end{array}$ & & $\begin{array}{c}0.366 \\
(0.009)\end{array}$ & \\
\hline Subcutaneous fat & $\begin{array}{c}0.513 \\
(0.001) \\
\end{array}$ & $\begin{array}{c}0.512 \\
(0.043)\end{array}$ & $\begin{array}{c}0.485 \\
(0.001) \\
\end{array}$ & $\begin{array}{c}0.708 \\
(0.002) \\
\end{array}$ & $\begin{array}{c}0.600 \\
(0.001) \\
\end{array}$ & $\begin{array}{c}0.734 \\
(0.001) \\
\end{array}$ & & & $\begin{array}{c}0.434 \\
(0.002) \\
\end{array}$ & $\begin{array}{c}0.583 \\
(0.018) \\
\end{array}$ \\
\hline Visceral fat & $\begin{array}{c}0.591 \\
(0.001)\end{array}$ & $\begin{array}{c}0.607 \\
(0.013) \\
\end{array}$ & $\begin{array}{c}0.661 \\
(0.001) \\
\end{array}$ & $\begin{array}{c}0.745 \\
(0.001) \\
\end{array}$ & $\begin{array}{c}0.587 \\
(0.001)\end{array}$ & $\begin{array}{c}0.622 \\
(0.010) \\
\end{array}$ & $\begin{array}{c}0.434 \\
(0.002) \\
\end{array}$ & $\begin{array}{c}0.583 \\
(0.018) \\
\end{array}$ & & \\
\hline $\begin{array}{l}\text { Subcutaneous fat/ } \\
\text { Visceral fat ratio }\end{array}$ & & & & & & & $\begin{array}{c}0.330 \\
(0.019) \\
\end{array}$ & & $\begin{array}{l}-0.615 \\
(0.001) \\
\end{array}$ & $\begin{array}{r}0.588 \\
(0.017) \\
\end{array}$ \\
\hline Arterial diameter Pre & & & & & & $\begin{array}{c}0.512 \\
(0.043) \\
\end{array}$ & & & & \\
\hline $\begin{array}{l}\% \text { Change in the arte- } \\
\text { rial diameter }\end{array}$ & & & & & & & $\begin{array}{l}-0.284 \\
(0.046)\end{array}$ & & & \\
\hline \% Change in PI & & & $\begin{array}{c}0.317 \\
(0.025) \\
\end{array}$ & & & & & & & \\
\hline \% Change in RI & & $\begin{array}{c}0.544 \\
(0.030)\end{array}$ & & & & $\begin{array}{c}0.555 \\
(0.026)\end{array}$ & $\begin{array}{c}0.274 \\
(0.054)\end{array}$ & $\begin{array}{c}0.516 \\
(0.041)\end{array}$ & & \\
\hline
\end{tabular}

Results represent Pearson correlation coefficient and only \% of change represents Spearman's $\rho$, and $p$ value in parenthesis

$\mathrm{BMI}$ - body mass index, WHR - waist hip ratio, PI - pulsatility index, RI - resistive index, Pre - pre hyperemic stimulus, \% - percentage

2.2 vs. $4.3 \pm 2.2, p<0.028)$ and a significant increase in $\mathrm{AD}(0.36 \pm 0.09 \mathrm{~cm}$ vs. $0.45 \pm 0.12 \mathrm{~cm}, p<0.001)$. In the group with $\mathrm{WHR}>0.85$, AD had a significant increase $(0.40 \pm 0.13 \mathrm{~cm}$ vs. $0.47 \pm 0.11 \mathrm{~cm}, p<0.004)$.

When dividing according to the time since menopause in those with $\leq 10$ years and more than 10 years there was a significant decrease in $\mathrm{Pl}$ in the first group (5.4 \pm 2.3 vs. $4.3 \pm 2.4, p<0.025)$ and also a significant increase in AD $(0.4 \pm 0.11 \mathrm{~cm}$ vs. $0.44 \pm 0.11 \mathrm{~cm}$, $p<0.001)$. In the group with more than 10 years there was an increase in $A D(0.42 \pm 0.14 \mathrm{~cm}$ vs. $0.5 \pm 0.12 \mathrm{~cm}$, $p<0.008)$.

\section{Discussion}

It is known that obesity is associated with a greater cardiovascular risk [4]. In this study, several parameters related to the cardiovascular risk were analyzed finding that WHR correlated with the diastolic blood pressure, which has already been reported $[10,13]$. It was also found that the skinfolds had a relationship with SF and VF, which has already been described [11]. Another study has reported a positive correlation of BMI, tricipital and subscapular ST with systolic blood pressure and triglyceride level [29].

With regard to the Doppler parameters, either in the whole group or in the subgroups, there was an increase in $\mathrm{AD}$ after the hyperemic stimulus among 6.5\% and $9 \%$, which is greater than that reported by another group [16] and indicates a healthy endothelium. However, there was only a decrease in PI in the whole group and in those with $\mathrm{BMI} \leq 27, \mathrm{WHR} \leq 0.85$ and time since menopause $\leq 10$ years, which represents that these low-risk groups have a better vascular reactivity. Low weight and lower body fat distribution have been related to a lower cardiovascular risk, and those with $\leq 10$ years since menopause have been reported to have healthy endothelium [30]. Skinfold thickness showed a relationship with the percentage of change in $\mathrm{PI}$ and $\mathrm{RI}$, and the subscapular skinfold is the most consistent in the whole group and in the subgroups, which makes it possible to detect the population at risk.

It is worth mentioning that the only negative correlations were observed between the percentage of change in $A D$ and the subscapular ST and SF in the whole group, and in groups with $\mathrm{BMI}>27$, and WHR $>0.85$, which means that the obesity and VF have an unfavorable effect in the endothelial environment [23].

With regard to the skinfolds, they had a negative correlation with $A D$ in the group with $B M I>27$ (subscapular skinfold) and WHR $>0.85$ (tricipital and suprailiac skinfold), which allows to conclude that the greater ST the greater endothelial compromise.

In those with $\leq 10$ years since menopause, there was a negative correlation between SF and the percentage of change in $A D$, while in the group with more than 10 years, the tricipital and subscapular skinfolds and SF correlated positively with the percentage of change in RI, which again indicates a greater cardiovascular risk. In those with more than 10 years since menopause, no significant changes were found in PI and in $A D$, which makes it possible to suspect that at 10 years since menopause, the endothelium is already affected [31]. 
However, this lack of response can be related either to late postmenopausal status or to age [32].

So it can be concluded that the ST measurement is related to VF and is another way for its evaluation. It can be inferred that greater ST is associated with increased endothelial environment compromise.

\section{Disclosure}

\section{Authors declare no conflict of interest.}

\section{References}

1. Mankad R, Best PJ. Cardiovascular disease in older women: a challenge in diagnosis and treatment. Womens Health 2008; 4: 449-464.

2. Carranza-Lira S, Guerrero Mills S, Castro A. Frecuencia del síndrome metabólico en mujeres posmenopáusicas mexicanas y su relación con la terapia hormonal. Ginecol Obstet Mex 2009; 77: 367-371.

3. Eshtiaghi R, Esteghamati A, Nakhjavani M. Menopause is an independent predictor of metabolic syndrome in Iranian women. Maturitas 2010, 65: 262-266.

4. Luckie DA, Cortés VF, Ibarra MS. Obesidad: trascendencia y repercusión médico-social. Revista de Especialidades Médico-Quirúrgicas 2009; 14: 191-201.

5. Koga R, Tanaka $\mathrm{H}$, Tsuda $\mathrm{H}$, et al. Daily exercise fluctuations and dietary patterns during training predict VF regain in obese women. Am J Med Sci 2008; 336: 450-457.

6. Anderson PJ, Chan JC, Chan YL, et al. VF and cardiovascular risk factors in Chinese NIDDM patients. Diabetes Care 1997; 20: 1854-1858.

7. Chiba Y, Sayito S, Takagi S, et al. Relationship between visceral fat and cardiovascular disease risk factors: the Tanoo and Sobetsu study. Hypertens Res 2007; 30: 229-236.

8. Zamboni M, Armellini F, Turcazo E, et al. Relationship between visceral fat, steroid hormones and insulin sensitivity in premenopausal obese women. J Intern Med 1994; 236: 521-527.

9. Ribeiro-Filho FF, Faria AN, Colman O, et al. Ultrasonography for the evaluation of visceral fat and cardiovascular risk. Hypertension 2001; 38 (3 Pt 2): 713-717.

10. Haines AP, Imeson JD, Meade TW. Skinfold thickness and cardiovascular risk factors. Am J Epidemiol 1987; 126: 86-94.

11. Reichly KB, Mueller WH, Hanis CL, et al. Centralized obesity and cardiovascular disease risk in Mexican Americans. Am J Epidemiol 1987; 125: 373-386.

12. Noppa H, Bengtsson C, Wedel H, Wilhelmsen L. Obesity in relation to morbidity and mortality from cardiovascular disease. Am J Epidemiol 1980; 111: 682-692.

13. Freedman DS, Katzmarzyk PT, Dietz WH, et al. The relation of BMI and skinfold thickness to risk factors among young and middle-aged adults: the Bogalusa Heart Study. Ann Hum Biol 2010; 37: 726-737.

14. Mombouli JV, Vanhoutte PM. Endothelial dysfunction from physiology to therapy. J Mol Cell Cardiol 1999; 31: 61-74.
15. Cai H, Harrison DG. Endothelial dysfunction in cardiovascular diseases: the role of oxidant stress. Circ Res 2000; 87: 840-844.

16. Faulx MD, Wright AT, Hoit BD. Detection of endothelial dysfunction with brachial artery ultrasound scanning. Am Heart J 2003; 145: 943-951.

17. Farouque HM, Meredith IT. The assessment of endothelial function in humans. Coron Artery Dis 2001; 12: 445-454.

18. Moens AL, Goovaerts I, Claeys MJ, Vrints CJ. Flow-Mediated vasodilation: a diagnostic instrument, or an experimental tool? Chest 2005; 127 2254-2263.

19. Takase B, Uehata A, Akima T, et al. Endothelium-dependent flow-mediated vasodilation in coronary and brachial arteries in suspected coronary artery disease. Am J Cardiol 1998; 82: 1535-1539.

20. Korkmaz H, Akbulut M, Ozbay Y. A new noninvasive method in evaluating the endothelial function: the measurement of the resistive index after reactive hyperemia of the brachial artery. Echocardiography 2010; 27: 873-877.

21. Staub D, Meyerhans A, Bundi B, et al. Prediction of cardiovascular morbidity and mortality: comparison of the internal carotid artery resistive index with the common carotid artery intima-media thickness. Stroke 2006; 37: 800-805.

22. Kumar V, Sachdev HP, Khalil A. Noninvasive evaluation of endothelia function and arterial mechanics in overweight adolescents. Indian Pediatr 2004; 41: 1105-1114

23. Marchesi S, Vaudo G, Lupattelli G, et al. Fat distribution and endothelial function in normal-overweight menopausal women. J Clin Pharm Ther 2007; 32: 477-482.

24. Técnica para la medición de los pliegues cutáneos en; available at: fuerzaypotencia.com/articulos/Download/tecnicapliegues.pdf.

25. Carranza-Lira S, Cuan-Martinez JR, Rosales-Ortiz S. Brachial artery responses in menopausal women using tibolone. Int J Gynaecol Obstet 2008; 101: 43-46.

26. Carranza-Lira S, Cirigo-Hernández B, Sandoval-Barragán MP, RamosLeón JC. Comparison of brachial artery vascular responses among postmenopausal women receiving different doses of tibolone. Int J Gynecol Obstet 2013; 122: 75-77.

27. Carranza-Lira S, Camarillo-Quesada AE, Ramos-León JC. Comparación de la flujometría Doppler de la arteria braquial en mujeres posmenopáu sicas mexicanas con y sin síntomas vasomotores. Ginecol Obstet Mex 2013; 81: 190-194.

28. Carranza-Lira S, Barcena-Jacobo TD, Sandoval-Barragán MP, Ramos León JC. Visceral adiposity after tibolone use. Int J Gynecol Obstet 2011; 115: 191-193.

29. Pavlica T, Mikalacki M, Matić R, et al. Relationship between BMI and skingold thickness to risk factors in premenopausal and postmenopausal women. Coll Antropol 2013; 37 Suppl 2: 119-124.

30. Harman SM. Menopausal hormone treatment cardiovascular disease: another look at an unresolved conundrum. Fertil Steril 2014; 101: 887 897.

31. Lenfant F, Trémollières F, Gourdy P, Arnal JF. Timing of the vascular ac tions of estrogens in experimental and human studies: why protective early, and not when delayed? Maturitas 2011; 68: 165-173.

32. Casiglia E, Tikhonoff V, Boschetti G, et al. Arterial stiffness and related variables across menopausal status: An epidemiologic study. J Womens Health 2013 ; 22: 75-84. 